\title{
Kenaikan Batas Usia Perkawinan Menurut Undang-Undang Nomor 16 Tahun 2019 dan Implikasinya Terhadap Kenaikan Angka Perkara Dispensasi Nikah di Pengadilan Agama Pemalang
}

\author{
Muhammad Nur Falah, Aufi Imaduddin, Kholisatul Ilmiyah
} UIN Walisongo Semarang, Institut Agama Islam Nahdlatul Ulama Tuban E-mail: mnurfalah@gmail.com, aufiabuzaya@gmail.com , Kholisatulilmiyah3@gmail.com

\begin{abstract}
Abstrak: Sejak mulai berlakunya Undang-Undang Nomor 16 Tahun 2019 Angka perkara dispensasi kawin melonjak. Sebagai contohnya terjadi di Kabupaten Pemalang yaitu sebanyak 951 permohonan. Berdasarkan Undang - Undang No.16 Tahun 2019 Tentang Perkawinan Pasal 7 Ayat(2) yang berbunyi "Dalam hal terjadi penyimpangan terhadap ketentuan umur sebagaimana dimaksud pada Ayat (1) orang tua pihak pria dan/atau orang tua pihak wanita dapat meminta dispensasi kepada Pengadilan denga alasan sangat mendesak disertai bukti-bukti pendukung yang cukup. Fokus penelitian ini adalah Kenaikan Batas Usia Perkawinan MenurutUndang- Undang Nomor 16 Tahun 2019 jo.UndangUndang Nomor 1 Tahun 1974tentang Perkawinan dan Implikasinya terhadap Kenaikan Angka Perkara Dispensasi Nikah Di Pengadilan Agama Pemalang. Metode penelitian menggunakan jenis penelitian yuridis empiris. Dengan menggunakan teknik pengumpulan data dengan menggunakan teknik wawancara dan dokumentasi. Hasil penelitian, Undang-undang Nomor 16 Tahun 2019 merupakan upaya pemerintah dalam mencegah pernikahan dini, sayangnya penetapan ini tidak dibarengi dengan perubahan aturan tentang dispensasi nikah sehingga semakin meningkat angka permohonan dispensasi nikah di Pengadilan Agama, hal ini disebabkan karena tidak adanya batasan yang jelas pada saat kapan dan dalam situasi apa pemberian dispensasi oleh pengadilan dan instansi berwenang diberikan. Kenyataan di lapangan menunjukkan bahwa jumlah perkara permohonan dispensasi nikah setelah ditetapkannya revisi Undang-Undang Pernikahan mengalami peningkatan di beberapa kota/kabupaten. Pengadilan Agama Pemalang mengalami kenaikan yang signifikan.

Kata kunci: Undang-undang Nomor 16 Tahun 2019, perkawinan, dispensasi nikah.
\end{abstract}




\section{Pendahuluan}

Pasal 1 Undang-Undang Nomor 1 Tahun1974 tentang Perkawinan, perkawinan adalah ikatan lahir batin antara seorang pria dengan seorang wanita sebagai suami istri dengan tujuan membentuk keluarga (rumah tangga) yang bahagia dan kekal berdasarkan Ketuhanan Yang Maha Esa. ${ }^{1}$

Tujuan dari perkawinan itu adalah untuk membentuk keluarga yang sakinah, mawaddah, warahmah.Untuk membentuk keluarga yang sakinah, mawaddah, warahmah tersebut, para pihak yang akan melangsungkan perkawinan hendaknya telah dewasa baik secara psikologis maupun biologis, serta mampu bertanggungjawab terhadap keluarga yang dibentuknya. Hal ini dilakukan karena hubungan hukum dilekatkan pada subyek hukum yang mampu untuk memikul hak dan kewajiban sebagai suami dan isteri. Oleh karena itu, tuntutan untuk melakukan perubahan terhadap Undang-Undang Perkawinan sangat penting dilakukan dan saat ini hukum yang hidup dalam tatanan hukum Nasional Indonesia harus mampu mengikuti dan menjawab permasalahan serta perkembangan masyarakat hukum yang terjadi di Indonesia. $^{2}$

Dalam Islam tidak ada aturan yang secara mutlak tentang batasan usia pernikahan, hanya saja Al-Quran mengisyaratkan bahwa orang yang akan melangsungkan pernikahan haruslah orang yang siap dan mampu, sebagaimana yang disebutkan dalam Quran Surat An-Nuur Ayat 32 yang artinya:

"Dan kawinkanlah orang-orang yang sendirian diantara kamu dan orang-orang yang layak (berkawin) dari hamba-hamba sahayamu yang perempuan. Jika mereka miskin, Allah akan memampukan mereka dengan karunia-Nya. Dan Allah Maha luas pemberian-Nya lagi maha mengetahui".

Kata layak (kawin) dipahami oleh ulama dengan makna mampu secara mental dan spiritual untuk membina rumah tangga. Begitu pula dengan hadist Rasulullah SAW, yang menganjurkan bagi para pemuda untuk melangsungkan perkawinan dengan syarat adanya kemampuan. As-Sayis mengutip pendapat Imam Abu Hanifah yang menyatakan bahwa anak dianggap baligh jika sudah berumur 18 tahun bagi laki-laki

\footnotetext{
${ }^{1}$ Wasman dan Wardah Nuroniyah, Hukum Perkawinan Islam di Indonesia Perbandungan Fiqh dan Hukum Positif, (Yogyakarta: CV. Citra Utama, 2011), hlm. 29.

2 Bambang Sutiyoso dan Sri Hastuti Puspitasari, Aspek-Aspek Perkembangan Kekuasaan Kehakiman di Indonesia, (Yogyakarta: UII Press, 2005), hlm 11.
} 
dan 17 tahu bagi perempuan.Sedangkan menurut Imam Syafi" ${ }^{\prime \prime}$ dan para pengikut Syafi'i (Syafi'iyah) berpendapat bahwa anak laki-laki ataupun perempuan sama-sama telah baligh sewaktu berumur 15 tahun.

Dispensasi kawin adalah untuk perkawinan yang calon mempelai laki-laki ataupun perempuannya masih di bawah umur dan belum diperbolehkan untuk menikah sesuai dengan peraturan perundangundangan yang berlaku. ${ }^{3}$ Sebagaimana yang telah diatur dalam UndangUndang No.1 Tahun 1974 tentang Perkawinan mengenai batasan umur terendah dalam melangsungkan perkawinan yaitu "Perkawinan hanya diizinkan jika pihak pria sudah mencapai umur 19 (sembilan belas) Tahun dan pihak wanita mencapai umur 16 (enam belas) Tahun", hal ini juga diatur dalam Pasal 15 Ayat(1) Kompilasi Hukum Islam.Kemudian Undang - Undang No.1 Tahun 1974 tentang perkawinan diamandemen menjadi Undang - Undang No.16 Tahun 2019 tentang perubahan atas Undang-UndangNo.1 Tahun 1974 tentang perkawinan mengenai batasan umur menjadi pria dan wanita menjadi umur 19 (Sembilan belas) tahun.

Dispensasi kawin diatur dalam Undang - Undang No.16 Tahun 2019 Tentang Perubahan Atas Undang - Undang Nomor 1 Tahun 1974 Tentang Perkawinan.

Pasal 7 Ayat(2) ${ }^{4}$

Dalam hal terjadi penyimpangan terhadap ketentuan umur sebagaimana dimaksud pada Ayat 1),orang tua pihak pria dan/atau orang tua pihak wanita dapat meminta dispensasi kepada Pengadilan denga alasan sangat mendesak disertai bukti-bukti pendukung yang cukup.

Tujuan diaturnya batasan umur dalam melangsungkan perkawinan adalah untuk mewujudkan tujuan dari perkawinan itu sendiri yaitu untuk membentuk keluarga yang bahagia dan kekal tanpa harus berakhir dengan adanya perceraian. Menurut Pasal 6 Ayat (2) Undang - Undang Nomor 1 Tahun 1974 tentang Perkawinan batas usia untuk melangsungkan perkawinan seorang yang belum mencapai umur 21 Tahun harus mendapat izin dari kedua orang tua. Jadi,bagi pria atau wanita yang telah mencapai umur 21 Tahun tidak perlu ada izin orang tua untuk melangsungkan perkawinan. Dalam Pasal 7 Undang-Undang

\footnotetext{
${ }^{3}$ www.pa-tasikmalaya.go.id/sop-dispensasi-kawin diakses Selasa 14 Januari 2020 pukul 14.00.

${ }^{4}$ Republik Indonesia, Undang-Undang RI Nomor 16 Tahun 2019 Tentang Perubahan atas Undang-Undang Nomor 1 Tahun 1974
} 
Nomor 1 Tahun 1974 tentang Perkawinan, yang perlu memakai izin orang tua untuk melakukan perkawinan adalah pria yang telah mencapai umur 19 Tahun. Disamping itu, dalam Undang - Undang Perkawinan juga diatur mengenai Dispensasi Kawin.

Sejak mulai berlakunya Undang-Undang Nomor 16 Tahun 2019 Tentang Perubahan atas Undang-Undang Nomor 1 Tahun 1974 tentang Perkawinan, Angka perkara dispensasi kawin melonjak.Sebagai contohnya terjadi di Kabupaten Pemalang. Berdasarkan data Permohonan Dispensasi Kawin Muda di Pengadilan Agama Pemalang terdapat angka sebagaimana dalam tabel di bawah ini :

\begin{tabular}{|c|c|c|}
\hline No & Tahun & Jumlah pemohon dispensasi \\
\hline 1 & 2018 & 84 \\
\hline 2 & 2019 & 168 \\
\hline 3 & 2020 & 699 \\
\hline
\end{tabular}

\section{Metode Penelitian}

Penelitian menggunakan metode pendekatan yuridis empiris. Penelitian yuridis empiris adalah penelitian hukum mengenai pemberlakuan atau implementasi ketentuan hukum normative secara in action pada setiap peristiwa hukum tertentu yang terjadi dalam masyarakat. ${ }^{5}$ Penelitian yuridis empiris merupakan penelitian lapangan yang menggunakan data primer yaitu dengan meneliti peraturanperaturan hukum yang kemudian di gabungkan dengan data dan perilaku yang hidup ditengah-tengah masyarakat. Jadi dalam hal ini, penelitian yang akan penulis lakukan berdasarkan pada data-data yang ada dan terjadi pada Pengadilan Agama Pemalang itu sendiri, tentang bagaimana proses berperkara dispensasi kawin itu setelah berlakunya Undang-Undang No.16 Tahun 2019 di Pengadilan Agama Pemalang.

\section{Dispensasi Kawin dan Batas Usia Perkawinan}

Dispensasi adalah penyimpangan atau pengecualian dari suatu peraturan. Dispensasi usia perkawinan memiliki arti keringanan akan sesuatu batasan (batasan umur) didalam melakukan ikatan antara seorang pria dengan seorang wanita sebagai suami isteri dengan tujuan

\footnotetext{
${ }^{5}$ Abdulkadir Muhammad,"Hukum dan Penelitian Hukum", (Bandung: Citra Aditya Bakti, 2004), hlm. 134.
} 
membentuk keluarga (rumah tangga) yang bahagia dan kekal berdasarkan Ketuhanan Yang Maha Esa. ${ }^{6}$

Dispensasi usia nikah diatur dalam Pasal 7 Ayat 1 dan Ayat 2 Undang-Undang Nomor 16 Tahun 2019. Dispensasi sebagaimana yang dimaksud dalam Undang - Undang Nomor 16 Tahun 2019 artinya penyimpangan terhadap batas minimum usia nikah yang telah ditetapkan oleh Undang - Undang yaitu minimal 19 Tahun bagi pria maupun bagi wanita. Oleh karena itu, jika pria maupun wanita yang belum mencapai usia nikah namun hendak melangsungkan perkawinan, maka pengadilan atau pejabat lain yang ditunjuk oleh kedua belah pihak dapat memberikan penetapan dispensasi usia nikah apabila permohonannya telah memenuhi syarat yang ditentukan dan telah melalui beberapa tahap dalam pemeriksaan, namun sebaliknya apabila pihak yang telah berperkara tidak memenuhi syarat yang telah ditentukan maka pihak pejabat dalam hal ini Pengadilan Agama tidak memberikan dispensasi untuk pernikahan kedua belah pihak tersebut.7

Baik dalam Undang-Undang Nomor 16 Tahun 2019 tentang Perkawinan maupun dalam KUHPerdata tidak disebutkan secara jelas dan pasti apa yang menjadi alasan untuk menerima suatu dispensasi nikah kepada pengadilan. Undang - Undang Perkawinan tidak menyebutkan apa saja yang dapat dijadikan alasan untuk meminta dispensasi tersebut. Jadi tiap-tiap keadaan dalam setiap kasus akan dipertimbangkan oleh pengadilan atau pejabat lain yang ditunjuk, sebagai misal calon mempelai wanita yang belum mencapai usia 19 Tahun dan telah hamil, maka untuk kenistaan wanita tersebut harus cepat-cepat dikawinkan agar anak yang dilahirkan kelak mempunyai bapak dan tidak dinamakan haram jadah. ${ }^{8}$

\section{Pasal 7 Undang-undang No 16 Tahun $2019^{9}$}

1. Perkawinan hanya diizinkan apabila pria dan wanita sudah mencapai umur 19 (sembilan belas) tahun.

2. Dalam hal terjadi penyimpangan terhadap ketentuan umur sebagaimana dimaksud pada ayat (1), orang tua pihak pria dan/atau

${ }^{6}$ R. Subekti dan R. Tjitrosoedibio, Kamus Hukum, (Jakarta: PT Pradnya Paramitha, 1996), hlm 35.

7 Taufik Hamami, Peradilan Agama dalam Reformasi Hakim di Indonesia, (Jakarta: PT Tata Nusa, 2013), hlm 31.

8 Ridwan Syahrani, Seluk Beluk dan Asas-Asas Hukum Perdata, (Bandung: Alumni, 1992), hlm 73.

9 Pasal 7, UU No 19 Tahun 2019 Tnetang Perkawinan. 
orang tua pihak wanita dapat meminta dispensasi kepada Pengadilan dengan alasan sangat mendesak disertai bukti-bukti pendukung yang cukup.

3. Pemberian dispensasi oleh Pengadilan sebagaimana dimaksud pada ayat (2) wajib mendengarkan pendapat kedua belah calon mempelai yang akan melangsungkan perkawinan.

4. Ketentuan-ketentuan mengenai keadaan seorang atau kedua orang tua calon mempelai sebagaimana dimaksud dalam Pasal 6 ayat (3) dan ayat (4) berlaku juga ketentuan mengenai permintaan dispensasi sebagaimana dimaksud pada ayat (2) dengan tidak mengurangi ketentuan sebagaimana dimaksud dalam Pasal 6 ayat (6).

Dalam hal permohonan dispensasi nikah yang dapat memintakan adalah:

1. Kedua orang tua baik dari pihak pria maupun wanita. (Pasal 6 Ayat 2 Undang - Undang Nomor 16 Tahun 2019)

2. Dalam hal salah seorang dari kedua orang tua telah meninggal dunia atau dalam keadaan tidak mampu menyatakan kehendaknya, makadapat dimintakan dari orang tua yang mampu menyatakan kehendaknya. (Pasal 6 Ayat 3 Undang - Undang Nomor 16 Tahun 2019)

3. Dalam hal kedua orang tua meninggal dunia atau tidak dapat menyatakan kehendaknya, maka yang meminta bisa wali, orang yang memelihara, atau keluarga yang mempunyai hubungan darah dalam garis keturunan lurus keatas selama mereka masih hidup dan dalam keadaan dapat menyatakan kehendaknya. (Pasal 6 Ayat 4 UndangUndang Nomor 16 Tahun 2019).

Permohonan dispensasi kawin diajukan oleh pihak pria maupun wanita calon mempelai. Permohonan dispensasi diajukan kepada Pengadilan Agama untuk yang beragama Islam, dan Pengadilan Negeri untuk yang beragama Non Islam. Dalam Islam tidak ada batasan usia dimana seseorang harus menikah, tetapi yang ditekankan adalah kesiapan untuk membina rumah tangga. Kesiapan disini dari segi ilmu, mental, dan ekonomi.Jadi dalam Islam pernikahan dini boleh dilakukan bahkan jika sudah sipa maka dianjurkan untuk menikah agar menjaga pandangan mata dankehormatan.

Sedangkan dalam Undang-undang perkawinan Indonesia, dijelaskan bahwa batasan usia dalam pernikahan disebutkan dalam Undang-Undang Nomor 16 Tahun 2019 Tentang Perkawinan bahwa perkawinan hanya diizinkan jika pihak pria dan pihak wanita sudah mencapai umur 19 
Tahun. Kompilasi Hukum Ilsma menyebutkan mengenai batasan usia dalam pernikahan adalah sesuai dengan UndangUndang Nomor 16 Tahun 2019. Ketentuan batas umur ini disebutkan seperti dalam Kompilasi Hukum Islam Pasal 15 Ayat (1) berdasarkan kepada pertimbangan kemaslahatan keluarga dan rumah tangga perkawinan.Ini sejalan dengan prinsip yang diletakan Undang - Undang perkawinan, bahwa calon suami dan calon isteri harus telah masuk jiwa dan raganya agar dapat mewujudkan tujuan perkawinan secara baik tanpa berakhir dengan perceraian dan mendapat keturunan yang baik dan sehat.Untuk itu harusdicegah adanya perkawinan antara calon suami dan calon isteri yang masih di bawah umur. ${ }^{10}$

Dalam perumusan Pasal 7 ayat (1) Undang - Undang No. 1 Tahun 1974 dimaksudkan untuk menjaga kesehatan suami istri dan keturunan, perlu ditetapkan batas-batas umur untuk perkawinan. ${ }^{11}$ Undang - Undang No. 1 Tahun 1974 menganut prinsip, bahwa calon suami istri itu harus telah masak jiwa raganya untuk dapat melangsungkan perkawinan, agar supaya dapat mewujudkan tujuan perkawinan secara baik tanpa berakhir pada perceraian dan mendapat keturunan yang baik dan sehat. Untuk itu harus dicegah adanya perkawinan diantara calon suami istri yang masih dibawah umur.Disamping itu perkawinan mempunyai hubungan dengan masalah kependudukan.Ternyatalah bahwa perkawinan mengakibatkan laju kelahiran yang lebih tinggi.Berhubung dengan itu, maka undangundang ini menentukan batas umur untuk kawin baik bagi pria 19 tahun maupun 16 tahun bagi wanita. ${ }^{12}$ Adapun ketentuan mengenai pencegahan perkawinan dalam Pasal 13 Undang - Undang No. 1 Tahun 1974 "Perkawinan dapat dicegah, apabila ada pihak yang tidak memenuhi syarat- syarat untuk melangsungkan perkawinan".Pencegahan perkawinan bertujuan untuk menghindari suatu perkawinan yang dilarang hukum Islam dan Peraturan Perundang-undangan. ${ }^{13}$

Dalam prakteknya pegawai pencatat perkawinan akan meneliti izin tertulis atau izin pengadilan sebagai dimaksud dalam Pasal 6 ayat (2), (3), (4), dan (5) Undang - Undang No. 1 Tahun 1974, apabila salah seorang calon mempelai atau keduanya belum mencapai umur 21 (dua puluh satu)

\footnotetext{
${ }^{10}$ Ahmad Rafiq, Hukum Islam di Indonesia, (Jakarta: Rajawali Press, 1998), hlm 76.

${ }^{11}$ Penjelasan pasal 7 ayat (1) Undang-undang Nomor 1 Tahun 1974 Tentang Perkawinan.

${ }^{12}$ Tim Permata Press, Kompilasi Hukum Islam (KHI), (t.tp., Permata Press, t.t), 103.

13 Pasal 60 ayat (1) Kompilasi Hukum Islam (KHI).
} 
tahun. Berdasarkan Pasal 16 Undang - Undang No. 1 Tahun 1974, pejabat yang ditunjuk berkewajiban mencegah perkawinan apabila ketentuan dalam Pasal 7 ayat (1) tidak dipenuhi. Kemudian Pasal 20 Undang Undang No. 1 Tahun 1974, mengatur pegawai pencatat perkawinan tidak diperbolehkan melangsungkan atau membantu melangsungkan perkawinan bila ia mengetahui adanya pelanggaran dari ketentuan Pasal 7 ayat (1), meskipun tidak ada pencegahan perkawinan.

Menurut pasal 66 Undang - Undang No. 1 Tahun 1974 menyatakan, untuk perkawinan dan segala sesuatu yang berhubungan dengan perkawinan berdasarkan atas undang-undang ini, maka dengan berlakunya undang-undang ini ketentuan-ketentuan yang diatur dalam Kitab Undang- undang Hukum Perdata dan peraturan-peraturan lain yang mengatur tentang perkawinan sejauh telah diatur dalam undangundang ini, dinyatakan tidak berlaku". Kaitannya dengan hal ini, batas usia minimal perkawinan menurut KUHPerdata ialah bagi laki-laki harus berumur sekurang-kurangnya 18 tahun, sedangkan bagi perempuan 15 tahun. Pasal 330 KUHPerdata menyatakan bahwa "dalam paham perkawinan tidaklah termasuk perkawinan anak-anak".

Berdasarkan Pasal 66 Undang - Undang No. 1 Tahun 1974, Pasal 7 Ayat (1) Undang - Undang No. 1 Tahun 1974 telah mengaturnya, maka ketentuan perbedaan batas usia minimal perkawinan dalam KUHPerdata di atas sudah tidak berlaku lagi. Namun, ketentuan dalam hal perkawinan anak-anak tidak ditemukan dalam Undang - Undang No. 1 Tahun 1974. Jadi ketentuan dalam Pasal 330 KUHPerdata tersebut masih berlaku.

Kenaikan Angka Perkara Dispensasi Nikah Di Pengadilan Agama Pemalang Pasca Undang-Undang Nomor 16 Tahun 2019 Tentang Perubahan UU No. 1 Tahun 1974 tentang Perkawinan

Dispensasi pernikahan di bawah umur merupakan sebuah wujud tindakan dari pemohon kepada hakim untuk memohon kebijakan dikarenakan ingin melangsungkan pernikahan namun belum cukup umur sesuai syarat dan ketentuan Undang - Undang Nomor 1 Tahun 1974 Tentang Perkawinan yaitu minimal usia pernikahan laki-laki 19 (sembilan belas) Tahun dan perempuan adalah 16 (enam belas) Tahun. Dan setelah berlakunya Undang - Undang Nomor 16 Tahun 2019 Tentang Perkawinan perubahan atas Undang - Undang Nomor 1 Tahun 1974 Tentang Perkawinan maka batas minimal usia pernikahan yang disebutkan dalam 
Pasal 7 Ayat (1) yaitu usia 19 (sembilan belas) Tahun bagi laki-laki maupun perempuan.

Adapun permohonan dispensasi nikah yang diterima dan ditolak di Pengadilan Agama Pemalang dari Tahun 2018 - 2020, dengan rincian sebagai berikut; ${ }^{14}$

\begin{tabular}{|l|c|c|c|c|c|}
\hline \multirow{2}{*}{ No } & \multirow{2}{*}{ Tahun } & \multicolumn{4}{|c|}{$\begin{array}{c}\text { Permohonan Dispensasi Nikah di Pengadilan } \\
\text { Agama }\end{array}$} \\
\cline { 3 - 6 } & & PemalangTahun 2018 - 2020 \\
\cline { 3 - 6 } & & 84 & 0 & 84 & 0 \\
\hline 1 & 2018 & 168 & 0 & 168 & 0 \\
\hline 2 & 2019 & 699 & 0 & 699 & 0 \\
\hline 3 & 2020 & 951 & 0 & 951 & 0 \\
\hline \multicolumn{7}{r|}{} & Total & & & & Diterima \\
\hline
\end{tabular}

Melihat data yang telah ditampilkan bahwa permintaan permohonan dispensasi nikah di Pengadilan Agama kabupaten Pemalang dai tahun 2018-2020 mengalami peningkatan yang sangat drastis. Hal ini disebabkan karena beberapa faktor yang mempengaruhinya. Permohonan dispensasi nikah di Pengadilan Agama pada tahun 2020 mengalami peningkatan yang sangat pesat dikarenakan sudah berlakunya Undang- Undang Nomor 16 Tahun 2019 Tentang Batas Usia Nikah, ditambah banyaknya keluarga yang memiliki latar belakang pendidikan yang kurang dan masalah ekonomi sehingga banyak yang mengajukan dispensasi nikah.

Pada Tahun 2020 sejak berlakunya Undang - Undang Nomor 16 Tahun 2019 perubahan atas Undang - Undang Nomor 1 Tahun 1974 maka mulai bulan Oktober 2019 sampai sekarang ketentuan yang digunakan untuk permohonan dispensasi nikah mengenai batas usia pernikahan berubah sesuai yang disebutkan pada Pasal 7 Ayat

(1) yaitu usia 19 (sembilan belas) Tahun bagi laki-laki maupun perempuan, daftar perkara masuk sejumlah 699 pemohon, dan dari 699 permohonan tersebut sudah putus dan dikabulkan oleh hakim dan tidak ada permohonan yang ditolak.

Ada beberapa asalan atau sebab kenapa masyarakat Pemalang

14 Wawancara H. Afif Eko Sulistiono, S.H. panitera pegadilan agama pemalang pada Rabu, 06 Januari 2021 
mengajukan permohonan dispensasi nikah ke Pengadilan Agama Pemalang. Ada yang beralasan kedua pasangan sudah siap untuk menjalin rumah tangga dan sanggup untuk menjalani hidup bersama, kemudia ada yang karena orang tua tidak memiliki pendidikan yang cukup sehingga mengganggap bahwa anak perempuanya sudah kenal lama dengan laki-laki harus segera dinikahkan karena ditakutkan akan hamil diluar nikah.

Menurut syarat dan ketentuan Undang - Undang Nomor 1 Tahun 1974 Tentang Perkawinan yaitu minimal usia pernikahan laki-laki 19 (sembilan belas) Tahun dan perempuan adalah 16 (enam belas) Tahun. Dan setelah berlakunya Undang-Undang Nomor 16 Tahun 2019 Tentang Perkawinan perubahan atas Undang-Undang Nomor 1 Tahun 1974 Tentang Perkawinan maka batas minimal usia 19 pernikahan yang disebutkan dalam Pasal 7 Ayat (1) yaitu usia 19 (sembilan belas) Tahun bagi laki-laki maupun perempuan.

Maka dari iu banyak sekaling masyarakat Kabupaten Pemlang yang mengajukan permohonan dispensasi nikah dikarenkan batas usia nikah mereka tidak memenuhi syarat dan ketentuan Undang - Undang Nomor 16 Tahun 2019 Tentang Perkawinan perubahan atas Undang - Undang Nomor 1 Tahun 1974 Tentang Perkawinan.

Analisa Undang-undang No 16 Tahun 2019 Tentang Batasan Usia Nikah

Undang-Undang nomor 16 tahun 2019 tentang batas usia nikah berarti termasuk dalam kategori Pembaharuan Hukum. Faktor-faktor yang mempengaruhi perubahan batas usia pernikahan di Indonesia, sesuai dengan isi Naskah Akademik Rancangan Undang-undang batas usia Pernikahan ada 3 landasan yaitu; ${ }^{15}$

1. Landasan Filosofis

Landasan Filosofis merupakan pertimbangan yang menggambarkan bahwa peraturan yang dibentuk mempertimbangkan pandangan hidup, cita, dan kesadaran hukum yang meliputi suasana kebatinan serta falsafah bangsa Indonesia yang bersumber pada Pancasila dan Pembukaan Undang-Undang Dasar Negara Republik Indonesia Tahun 1945.

Secara Filosofis, perubahan batas usia nikah bagi perempuan dari 16 tahun menjadi 19 tahun sehingga sama dengan laki-laki,

15 Naskah Akademik Rancangan Undang-Undang Nomor 16 Tahun 2019 Tentang Perubahan Atas Undang-Undang Nomor 1 Tahun 1974 Tentang Perkawinan, hlm 25-29 
merupakan komitmen negara dalam mewujudkan kehidupan berbangsa dan bernegara yang jauh dari perlakuan diskriminatif terhadap anak perempuan sebagai warga negara dan menjaga hakhak anak dari pemenuhan hak kesehatan dan hak pendidikan.

Sehingga dengan terjaminnya hak-hak tersebut mereka dapat tumbuh dan berkembang dengan baik mampu memaksimalkan potensi yang dimiliki dan menjadi anak-anak yang berkualitas dan diharapkan mereka akan menjadi penerus-penerus bangsa yang lebih baik serta dapat mewujudkan cita-cita bangsa Indonesia.

2. Landasan Sosiologis

Landasan Sosiologis merupakan pertimbangan peraturan yang dibentuk untuk memenuhi kebutuhan masyarakat dalam berbagai aspek yang menyangkut fakta empiris mengenai perkembangan masalah dan kebutuhan masyarakat dan negara.

Dalam praktik pernikahan anak di Indonesia merupakan persoalan yang selalu muncul dari waktu ke waktu, sejak era penjajahan kolonial hingga saat ini.Pada masa kolonial ditemukan kasus-kasus dimana anak perempuan dinikahkan pada usia yang cukup muda, seperti 8 atau 10 tahun. Praktek pernikahan anak yang menimbulkan kekerasan dan ekploitasi seksual telah berlangsung cukup lama.Respon Negara kolonial baru muncul pada sekitar tahun 1890 ditandai dengan adanya dorongan agar persetubuhan terhadap anak termasuk di dalam pernikahan dianggap sebagai perbuatan perkosaan dan diadili di pengadilan.

Maka scara sosiologis, penetapan Undang-undang Nomor 16 Tahun 2019 merupakan upaya pemerintah dalam mencegah pernikahan dini, sayangnya penetapan ini tidak dibarengi dengan perubahan aturan tentang dispensasi nikah sehingga semakin meningkat angka permohonan dispensasi nikah di Pengadilan Agama, hal ini disebabkan karena tidak adanya batasan yang jelas pada saat kapan dan dalam situasi apa pemberian dispensasi oleh pengadilan dan instansi berwenang diberikan. Kenyataan di lapangan menunjukkan bahwa jumlah perkara permohonan dispensasi nikah setelah ditetapkannya revisi Undang-Undang Pernikahan mengalami peningkatan di beberapa kota/kabupaten. PTA Semarang mencatat bahwa pasca revisi Undang-Undang Pernikahan, Pengadilan Agama Pemalang mengalami kenaikan yang signifikan yang mana 
sebelumnya pada tahun 2018 berjumlah 81 perkara, sedangkan pada tahun 2020 pasca perubahan Undang-Undang mengalami kenaikan drastis mencapai 699 perkara. Fakta di atas menunjukkan bahwa revisi Undang-Undang Pernikahan yang ada ternyata tidak sebanding dengan kesadaran hukum masyarakat.

3. Landasan Yuridis

Landasan Yuridis merupakan pertimbangan peraturan yang dibentuk untuk mengatasi permasalahan hukum atau mengisi kekosongan hukum dengan mempertimbangkan aturan yang telah ada, yang akan diubah, atau yang akan dicabut guna menjamin kepastian hukum dan rasa keadilan masyarakat. Landasan Yuridis menyangkut persoalan hukum yang berkaitan dengan substansi atau materi yang diatur sehingga perlu dibentuk peraturan perundangundangan yang baru. Beberapa persoalan hukum itu, antara lain, peraturan yang sudah ketinggalan, peraturan yang tidak harmonis atau tumpang tindih, jenis peraturan yang lebih rendah dari Undangundng sehingga daya berlakunya lemah, peraturannya sudah ada tapi tidak memadai, atau peraturannya memang sama sekali belum ada.

Maka secara Yuridis, perubahan batas usia nikah adalah revisi dari peraturan sebelumnya yang dianggap sudah tidak relevan dengan kondisi masyarakat sekarang baik dari sisi kesehatan biologis, psikologis, ekonomi, pendidikan dan kebudayaan. Pasal 7 ayat 1 Undang-undang Nomor 1 Tahun 1974 tumpang tindih atau tidak sinkron dengan Undang-undang Perlindungan Anak dan UndangUndang Dasar Negara Republik Indonesia tahun 1945, sehingga aturan mengenai batas usia nikah sekarang terdapat dalam Undangundang Nomor 16 Tahun 2019, yaitu Pernikahan hanya diizinkan apabila pria dan wanita sudah mencapai umur 19 (sembilan belas) tahun. Dan ini adalah wujud dari kepastian hukum.

Analisis kenaikan batas usia perkawianan menurut No 16 Tahun 2019 dan Implikasinya Terhadap Kenaikan Angka Perkara Dispensasi Nikah di Pengadilan Agama Pemalang

Menurut syarat dan ketentuan Undang-Undang Nomor 1 Tahun 1974 Tentang Perkawinan yaitu minimal usia pernikahan laki-laki 19 (sembilan belas) Tahun dan perempuan adalah 16 (enam belas) Tahun. Dan setelah berlakunya Undang-Undang Nomor 16 Tahun 2019 Tentang Perkawinan perubahan atas Undang - Undang Nomor 1 Tahun 1974 Tentang Perkawinan maka batas minimal usia 19 pernikahan yang disebutkan 
dalam Pasal 7 Ayat (1) yaitu usia 19 (sembilan belas) Tahun bagi laki-laki maupun perempuan.

Maka dari itu banyak sekaling masyarakat Kabupaten Pemalang yang mengajukan permohonan dispensasi nikah dikarenkan batas usia nikah mereka tidak memenuhi syarat dan ketentuan Undang - Undang Nomor 16 Tahun 2019 Tentang Perkawinan perubahan atas Undang - Undang Nomor 1 Tahun 1974 Tentang Perkawinan.

Banyaknya angka pengajuan permohonan dispensasi nikah disebabkan karena banyak anak-anak yang sudah melakukan hubungan dengan lawan jenis dan banyaknya anak yang tidak sekolah dikarenakan pandemi yang melanda Indonesia. Maka para orang tua khawatir anakanaknya akan melakukan hal-hal yang tidak diinginkan, sehingga orang tua membuat permohonan dispensasi nikah untuk anaknya bisa menikah.

Maka dapat dipaparkan bahwasanya pengajuan dispensasi nikah di Pengadilan Agama Pemalang ini di pengaruhi oleh beberapa faktor yaitu;

1. Permasalahan ekonomi dan rendahnya pendidikan

Berdasar dari data setelah wawancara di Pengadilan Agama Pemalang, permasalahan ekomoni sering menjadi alasan permohonan dispensasi nikah yang berasal dari daerah-daerah pelosok Kabupaten Pemalang. Keter batasan ekonomi untuk menyekolahkan anaknya kejenjang berikutnya menjadi alasan orang tua untuk menikahkan anaknya meskipun umurnya belum mencukupi untuk melangsungkan pernikahan. Dengan harapan agar beban orang tua menjadi ringan jika anaknya sudah menikah dan sudah tidak tinggal bersama orang tuanya.

Permasalahan ekonomi menjadikan dasar ini berkorelasi dengan dasar karena rendahnya pendidikan. Karena orang tua yang terhimpit ekonomi sehingga tidak mampu membiayai anaknya sekolah dan mengakibatkan pendidikan anaknya menjadi rendah.Tidak sedikit dari pemohon yang hanya mempunyai lulusan SMP bahkan SD. Dengan keterbatasan pengetahuan mereka, dan awamnya mereka terhadap Undang - Undang yang berlaku menjadikan mereka tidak mengetahui mengenai batasan usia dalam perkawinan. Mereka juga tidak mengetahui akibat yang akan terjadi dimasa depan karena menikahkan anaknya yang masih belum cukup umurnya. Pada usia remaja seharusnya anak masih dalam pengampuan orang tuanya. Apalagi masa kini kemampuan teknologi semakin canggih.Akan 
menjadi boomerang yang buruk jika salah dalam penggunaannya dan berdampak negatif kepada anak..

2. Calon mempelai wanita sudah hamil terlebih dahulu

Sepasang kekasih dalam menjalin hubungan terkadang sudah melampaui batas, bahkan mereka sudah berhubungan suami isteri meskipun belum dalam ikatan perkawinan yang sah dan berakibat pihak wanita hamil diluar nikah. Bagi perempuan yang masih di bawah umur, sangat tidak dianjurkan untuk menikah dalam usia dini. Karena tingkat kematangan reproduksi belum sempurna. Hakim tidak dapat menolak permohonan dengan alasan faktor ini karena akan berdampak buruk bagi calon mempelai wanita yang sudah dalam kondisi hamil dan juga kedudukan anak jika nanti sudah lahir.

Dapat disimpulkan bahwa permohonan dispensasi nikah dengan dasar pertimbangan karena calon isteri sudah dalam keadaan hamil harus dikabulkan karena terdapat Undang - Undang yang menjadi legalitas penyimpangan batasan umur pernikahan, kemudian dalam pandangan Islam kejadian tersebut adalah perbuatan zina dan haram baginya seorang yang berzina menikah dengan orang mukmin atau orang yang tidak berzina. Hal ini akan menjadikan dosa besar dan aib bagi keluarganya jika tidak segera dihentikan, maka dengan cara melangsungkan pernikahan antara kedua belah pihak atau bertaubat serta akan berdampak bagi keluarga para pemohon serta terjamin kedudukan calon bayi ketika sudah lahir nanti, dengan ketentuan calon suami akan bertanggung jawab penuh terhadap hak isteri dan anaknya.

Berlakukanya Undang-Undang No.16 Tahun 2019 Tentang Perubahan Atas Undang-Undang Nomor 1 Tahun 1974 membuat permohonan dispensasi nikah di pengadilan agama Pemalang semakin meningkat, hal ini disebabkan oleh bertambahnya syarat permohonan nikah muda, dari yang awalnya usia 19 Tahun untuk pria dan wanita usia 16 Tahun menjadi usia 19 Tahun untuk pria dan wanita. Data permohonan di pengadilan agama pemalang di Tahun 2018 permohonan berjumlah 84 pemohon meningkat sangat drastis diTahun 2020 dengan 699 pemohon, hal ini sangat mempengaruhi jumlah permohonan dispensasi di Pengadilan agama pemalang.

Melihat data tersebut hal ini imbas dari berlakunya UndangUndang tersebut sangatlah signifikan sehingga menimbulkan 
lonjakan yang amat besar, selain dari faktor - faktor yang telah disampaikan juga ada faktor lain yaitu adanya wabah pandemi covid19, yang menimbulkan banyaknya anak yang putus sekolah karena orang tuanya khawatir anaknya melakukan hubungan di luar nikah, sehingga memohon pengajuan dispensasi nikah ke pengadilan agama pemalang.

\section{Penutup}

Undang-undang Nomor 16 Tahun 2019 tentang batas usia nikah memiliki pengaruh terhadap hukum pernikahan, yaitu: Secara Filosofis, perubahan batas usia nikah bagi perempuan dari 16 tahun menjadi 19 tahun sehingga sama dengan laki-laki, merupakan komitmen negara dalam mewujudkan kehidupan berbangsa dan bernegara yang jauh dari perlakuan diskriminatif terhadap anak perempuan sebagai warga negara dan menjaga hak-hak anak dari pemenuhan hak kesehatan dan hak pendidikan. Secara Sosiologis, penetapan Undang-undang Nomor 16 Tahun 2019 merupakan upaya pemerintah dalam mencegah pernikahan dini, sayangnya penetapan ini tidak dibarengi dengan perubahan aturan tentang dispensasi nikah sehingga semakin meningkat angka permohonan dispensasi nikah di Pengadilan Agama. Secara Yuridis, perubahan batas usia nikah adalah revisi dari peraturan sebelumnya yang dianggap sudah tidak relevan dengan kondisi masyarakat sekarang baik dari sisi kesehatan biologis, psikologis, ekonomi, pendidikan dan kebudayaan.

Sejak tahun 2018-2020 banyak sekali masyarakat yang melakukan pengajuan permohonan dengan jumlah total adalah 951 permohoanan. Pada tahun 2020 merupakan jumlah paling banyak masyarakat Kabupaten Pemalang mengajukan permohonan yaitu 699 permohonan. Ini artinya terjadi kenaikan angka yang mengajukan dispensasi nikah, sejak diubahnya batas minimum perkawinan berdasarkan UU No. 16 Tahun 2019 tentang Perubahan UU No. 1 Tahun 1974. Hal itu disebabkan karena banyak anak-anak yang sudah melakukan hubungan dengan lawan jenis dan banyaknya anak yang tidak sekolah dikarenakan pandemi yang melanda Indonesia. Maka para orang tua khawatir anak-anaknya akan melakukan hal-hal yang tidak diinginkan, sehingga orang tua membuat permohonan dispensasi nikah untuk anaknya bisa menikah. 


\section{Daftar Pustaka}

Undang-undang No 16 Tahun 2019 Jo. Undang-undang No 1 Tahun 1974 Tentang Perkawinan

Kompilasi Hukum Islam.

Undang-undang No 23 Tahun 2002 Tentang Perlindungan Anak .

Naskah Akademik Rancangan Undang-Undang Nomor 16 Tahun 2019

Tentang Perubahan Atas Undang-Undang Nomor 1 Tahun 1974 Tentang Perkawinan.

Abdulkadir Muhammad. Hukum dan Penelitian Hukum. Bandung: Citra Aditya Bakti, 2004.

Ahmad Rafiq. Hukum Islam di Indonesia. Jakarta: Rajawali Press, 1998.

Bambang Sutiyoso dan Sri Hastuti Puspitasari. Aspek-Aspek Perkembangan Kekuasaan Kehakiman di Indonesia. Yogyakarta: UII Press, 2005.

R. Subekti dan R. Tjitrosoedibio. Kamus Hukum. Jakarta: PT Pradnya Paramitha, 1996.

Ridwan Syahrani. Seluk Beluk dan Asas-Asas Hukum Perdata. Bandung: Alumni, 1992.

Taufik Hamami. Peradilan Agama dalam Reformasi Hakim di Indonesia, Jakarta: PT Tata Nusa, 2013.

Wasman dan Wardah Nuroniyah. Hukum Perkawinan Islam di Indonesia Perbandingan Figh dan Hukum Positif. Yogyakarta: CV. Citra Utama, 2011.

Wawancara H. Afif Eko Sulistiono, S.H. panitera pengadilan agama Pemalang. www.pa-tasikmalaya.go.id/sop-dispensasi-kawin. 